\title{
Saccharification of Parthenium hysterophorus biomass using cellulase from Streptomyces sp. NAA2
}

\author{
Anita Saini $^{1}$ • Neeraj K. Aggarwal ${ }^{1}$ \\ Received: 15 July 2018 / Accepted: 27 February 2019 / Published online: 7 March 2019 \\ (C) Università degli studi di Milano 2019
}

\begin{abstract}
Parthenium hysterophorus biomass can be used as a non-conventional renewable feedstock for the production of bioethanol. Therefore, the present work was designed to hydrolyze $P$. hysterophorus biomass using cellulase enzyme produced from an actinomycete, i.e., Streptomyces sp. NAA2 using P. hysterophorus biomass as a substrate. The isolate NAA2 was identified by molecular characterization of $16 \mathrm{SrDNA}$. The enzyme production by strain NAA2 was enhanced by optimization studies conducted under submerged fermentation conditions using $P$. hysterophorus as a substrate. The crude enzyme produced under optimized conditions was used to hydrolyze alkali-acid pretreated $P$. hysterophorus biomass. The highest CMCase production was achieved in 4-5 days when steam-pretreated P. hysterophorus biomass was used at $1 \%(w / v)$ concentration, using 2 discs $(1$ disc $=5 \times 10^{7}$ spores $/ \mathrm{ml}$ ) of inoculum, an initial $\mathrm{pH} 6.5$, temperature at $40{ }^{\circ} \mathrm{C}$, an agitation speed of $120-150 \mathrm{rpm}$, and by supplementing fermentation medium with $1.5 \%(w / v)$ carboxymethyl cellulose $(\mathrm{CMC})$ as additional carbon source. Under optimized conditions, the actinomycete strain NAA2 showed production of $0.967 \pm 0.016 \mathrm{U} / \mathrm{ml} \mathrm{CMCase,} 0.116 \pm 0.08 \mathrm{FPU} /$ $\mathrm{ml} \mathrm{FPase}$, and $0.22 \pm 0.012 \mathrm{U} / \mathrm{ml} \beta$-glucosidase enzymes. On utilizing the cellulase enzyme for biomass hydrolysis, maximum $18.2 \%$ saccharification yield (of cellulose $0.202 \mathrm{~g} / \mathrm{g}$ ) was achieved in $96 \mathrm{~h}$ when enzyme and substrate levels were $30 \mathrm{FPU} /$ $100 \mathrm{ml}$ and $2 \%(w / v)$ respectively. Parthenium hysterophorus biomass can be hydrolyzed enzymatically yielding considerable amounts of total reducing sugars. It can, therefore, be used as a feedstock for the production of bioethanol. Also, it has the potential to act as a substrate for the production of cellulases. Furthermore, the improved cellulolytic potential of Streptomyces sp. NAA2 can be exploited in various industrial applications.
\end{abstract}

Keywords Actinomycete $\cdot$ Biomass hydrolysis $\cdot$ Cellulase $\cdot$ Parthenium hysterophorus $\cdot$ Streptomyces

\section{Introduction}

In the past few decades, there has been a growing interest in renewable fuels such as biofuels to meet the energy demands of the rising population in the world (Escobar et al. 2009). The bioethanol produced from lignocellulosic biomass is considered as a sustainable as well as an attractive transport fuel due to its compatibility with the existing engines (Sukumaran et al. 2009). Recent studies are focused on various aspects of the process of bioethanol production from lignocellulose to make its commercialization feasible in the near future. One of the essential factors to be considered for this is the availability and

Neeraj K. Aggarwal

neerajkuk26@rediffmail.com

1 Department of Microbiology, Kurukshetra University, Kurukshetra, Haryana 136119, India exploitability of diverse lignocellulosic biomass (Sukumaran et al. 2009). Nowadays, various scientific communities, therefore, have started to explore the potential of non-conventional feedstock for its bioconversion to ethanol.

Parthenium hysterophorus, one of the world's most noxious weeds, is found in various countries of Asia, Africa, America, and Australia (Saini et al. 2014). The weed is known for its high adaptability over a wide range of environmental conditions and has been successful in naturalizing various habitats owing to its high reproduction potential and allelopathic effect on many other plant species (Gnanavel 2013). The various physical, chemical, biological, and integrated management strategies employed for its control until now have been unsuccessful in many parts of the world. However, the weed can be used in various other applications. It is known to have various medicinal properties such as cytotoxic, anti-cancer, anti-oxidant, and antimicrobial activities and various other pharmacological effects (Saini et al. 2014). 
Also, the weed biomass can be utilized as a substrate for the production of lignocellulolytic enzymes and as a feedstock for bioethanol production.

The cellulosic ethanol production process involves several crucial steps such as biomass pretreatment for its cell wall deconstruction, hydrolysis of sugar polymers (cellulose and/ or hemicellulose) to release fermentable sugars, and finally fermentation of sugars to ethanol (Sarkar et al. 2012). The hydrolysis of cellulose (or saccharification) involves the use of cellulases, a complex of endoglucanases (EC 3.2.1.4), cellobiohydrolases (EC 3.2.1.74), and $\beta$-glucosidases (EC 3.2.1.21) enzymes (Padilha et al. 2015). The complete cellulose hydrolysis involves synergistic action of all these enzymes, which cleave $\beta$-1,4-glycosidic linkages between glucose units in cellulose polymer at different locations. The cellulases are produced by a wide array of microorganisms, including both fungi and bacteria (Sadhu and Maiti 2013; Imran et al. 2016). The Actinobacteria are a group of microorganisms largely known for their secondary metabolite production potential and are also recognized among major lignocellulose decomposers in nature (Bettache et al. 2014).

Keeping the above factors in mind, the present study was designed to enhance cellulase production from Streptomyces sp. NAA2 using $P$. hysterophorus biomass as a substrate under submerged fermentation ( $\mathrm{SmF}$ ) conditions and then utilizing the enzyme produced after optimization studies in saccharification of $P$. hysterophorus biomass.

\section{Materials and methods}

\section{Microbial isolate}

The actinomycete isolate Streptomyces sp. NAA2 was originally isolated from waste land soil (Saini et al. 2016). Starch casein agar medium (SCA) containing ( $w / v) 1 \%$ starch, $0.03 \%$ casein, $0.2 \% \mathrm{KNO}_{3}, 0.2 \% \mathrm{NaCl}, 0.2 \% \mathrm{~K}_{2} \mathrm{HPO}_{4}, 0.005 \%$ $\mathrm{MgSO}_{4} \cdot 7 \mathrm{H}_{2} \mathrm{O} ; 0.002 \% \mathrm{CaCO}_{3}, 0.001 \% \mathrm{FeSO}_{4} \cdot 7 \mathrm{H}_{2} \mathrm{O}$, and $2 \%$ agar ( $\mathrm{pH} 7.0)$, was used for maintaining and preserving isolate at $30{ }^{\circ} \mathrm{C}$ and $4{ }^{\circ} \mathrm{C}$ respectively.

\section{Molecular identification of the isolate NAA2}

The isolate was characterized genetically using commercial service provided by Eurofins Genomics India Pvt. Ltd., Bangalore, India. The DNA was extracted using the standard protocol. From the isolated DNA, the fragment of the $16 \mathrm{~S}$ rDNA gene was amplified by PCR using Act283F (5'GGGTAGCCGGCCUGAGAGGG-3') and Act1360R (5'CTGATCTGCGATTACTAGCGACTCC-3') primers. Thereafter, the PCR amplicons were purified to remove contaminants, and sequencing was done using BDT v3.1 Cycle sequencing kit on ABI 3730xl Genetic Analyzer. The 16S
rDNA sequence was then compared to available data in EzTaxon e-server (Kim et al. 2012) to determine close relatives of the isolate NAA2. The multiple sequence alignments were performed using CLUSTALX version 2.1 (Thompson et al. 1997). DAMBE (data analysis in molecular biology and evolution) software (Xia and Xie 2001) was used for manual editing of alignment to get unambiguous data. Neighbor-joining end method was used to construct the phylogenetic dendrogram using MEGA 7.0 (Molecular Evolutionary Genetics Analysis, version 7.0) software (Kumar et al. 2016). Bootstrap analysis was done with 1000 replicas. The 853 bp long sequence was deposited in the GenBank (National Centre for Biotechnology Information, NCBI) with accession number MF632248.

\section{Biomass processing and pretreatment}

The Parthenium hysterophorus biomass, collected from local areas, was first washed thoroughly to remove dirt and then chopped into small pieces. Thereafter, it was dried completely (overnight) at $50-60{ }^{\circ} \mathrm{C}$ followed by grinding to powder with a particle size $<1 \mathrm{~mm}$.

For steam pretreatment, powdered biomass was soaked in distilled water and then autoclaved at $121^{\circ} \mathrm{C}(15$ pounds per square inch or psi pressure) for a retention time of $30 \mathrm{~min}$. In alkali-acid (combined) pretreatment, biomass was subjected to alkali pretreatment (using $1.5 \% \mathrm{w} / \mathrm{v} \mathrm{NaOH}$, at $121{ }^{\circ} \mathrm{C}$ for $30 \mathrm{~min}$ ) followed by acid pretreatment (using $0.5 \% \mathrm{v} / \mathrm{v}$ $\mathrm{H}_{2} \mathrm{SO}_{4}$, at $121^{\circ} \mathrm{C}$ for $30 \mathrm{~min}$ ). During both pretreatments, bath ratio was kept as 1:10, and the pressure of the autoclave was released swiftly after completion of retention time in the autoclave. After each pretreatment, the biomass was dried completely (overnight) at $60^{\circ} \mathrm{C}$.

\section{Optimization of enzyme production}

The inoculum was developed by cultivating NAA2 isolate on starch casein agar medium at $30-35^{\circ} \mathrm{C}$ for $4-5$ days till sporulation was completed. The cellulase production was carried out under SmF conditions using P. hysterophorus biomass as a substrate. For fermentation, Mandel's medium ( $\mathrm{pH} 7.0$ ) (Mandels and Reese 1957) was used with little modifications. The medium contained $(\mathrm{g} / \mathrm{l})$ urea $(0.3)$, ammonium sulfate (1.4), $\mathrm{KH}_{2} \mathrm{PO}_{4}$ (2.0), $\mathrm{CaCl}_{2} \cdot \mathrm{H}_{2} \mathrm{O}(0.3), \mathrm{MgSO}_{4} \cdot 7 \mathrm{H}_{2} \mathrm{O}(0.3)$, and trace element solution. The trace element solution contained (mg/l) $\mathrm{FeSO}_{4} \cdot 7 \mathrm{H}_{2} \mathrm{O}(5), \mathrm{MnSO}_{4} \cdot \mathrm{H}_{2} \mathrm{O}$ (16), $\mathrm{ZnCl}_{2}$. $7 \mathrm{H}_{2} \mathrm{O}(14)$, and $\mathrm{CoCl}_{2} \cdot 6 \mathrm{H}_{2} \mathrm{O}(2.0)$. For enzyme production, $25 \mathrm{ml}$ of production medium was taken in a $250-\mathrm{ml}$ Erlenmeyer flask and inoculated with 1 disc of inoculum (diameter $8 \mathrm{~mm}=5 \times 10^{7}$ spores/ $\mathrm{ml}$ ). The fermentation was done at $35^{\circ} \mathrm{C}$ temperature for 4 days under shaking conditions at $150 \mathrm{rpm}$. 
The enzyme production by Streptomyces sp. NAA2 was enhanced by optimization of fermentation conditions using "one variable at a time" approach. First, the effect of biomass pretreatment was studied by supplementing fermentation medium with $1 \%(w / v)$ of the $P$. hysterophorus biomass subjected to different pretreatments. Next, the effect of substrate concentration was examined by varying its concentration from $0.5 \%$ to $2.5 \%(w / v)$ in the fermentation medium. The influence of inoculum size was evaluated by inoculating production medium with different amounts of the inoculum, i.e., 1 to 5 discs. To know the effect of $\mathrm{pH}$, initial $\mathrm{pH}$ of the medium was varied over a range of 5.5 to 9.0 . The effect of temperature was observed from $25^{\circ} \mathrm{C}$ to $45^{\circ} \mathrm{C}$ (varied at an interval of $5^{\circ} \mathrm{C}$ ). The effect of incubation period was investigated from 2 to 8 days. Furthermore, supplementation of medium (containing biomass substrate) with additional carbon sources may enhance the enzyme production by the microbes. Therefore, the effect of additional carbon source was observed by adding $1 \%(w / v)$ of different carbon sources, viz., glucose, fructose, galactose, cellobiose, lactose, sucrose, CMC, starch, and mannitol, in the fermentation medium. The effect of carbon source concentration was also studied by varying its level in the medium from $0.25 \%$ to $2.5 \%(w / v)$. Also, the effect of agitation speed was studied by varying the shaking speed from 100 to $180 \mathrm{rpm}$.

\section{Biomass saccharification}

The $P$. hysterophorus biomass pretreated by alkali-acid pretreatment was used for saccharification by crude enzyme obtained from Streptomyces sp. NAA2. The crude enzyme was first concentrated by acetone precipitation method (Choudhary et al. 2014). For the hydrolysis, the biomass was mixed with $100 \mathrm{mM}$ citrate buffer $(\mathrm{pH} 4.8)$ and crude enzyme and was further added with $0.03 \%$ sodium azide to avoid microbial contamination. The incubation was done at $50{ }^{\circ} \mathrm{C}$ at $120 \mathrm{rpm}$. The effect of substrate concentration was studied by varying the amount of pretreated biomass from $1.0 \%$ to $7.0 \%(w / v)$. To study the effect of enzyme loadings, the amount of the enzyme was varied in reaction volume $(100 \mathrm{ml})$ in FPU and total volume was made with citrate buffer. The progress of hydrolysis was monitored for 4 days $(96 \mathrm{~h})$ at an interval of $24 \mathrm{~h}$. After completion of the reaction, the hydrolysate was subjected to centrifugation at $10,000 \mathrm{rpm}$ for 15-20 $\mathrm{min}$ and the supernatant was assayed for total reducing sugars (TRS) released in hydrolysis process (Miller 1959). The saccharification yield was calculated using the formula:

Saccharication yield $(\%)=\frac{\text { Reducing sugars released }}{\text { Cellulose content in biomass }} \times 0.9 \times 100$

where 0.9 is the conversion coefficient from glucan to reducing sugars.

\section{Enzyme assays}

The extracellular enzyme was extracted by separating liquid medium from solid biomass by filtration through muslin cloth followed by centrifugation at $4{ }^{\circ} \mathrm{C}$ at $10,000 \mathrm{rpm}$ for $20 \mathrm{~min}$. The supernatant was filtered through Whatman filter paper no. 1 to obtain crude enzyme extract.

The carboxymethyl cellulase (CMCase or endoglucanase activity) and FPase (Filter paper activity) were assayed using the method by Ghose (1987). For CMCase assay, $0.5 \mathrm{ml}$ of the appropriately diluted enzyme was mixed with $0.5 \mathrm{ml}$ of $1 \%$ $(w / v)$ carboxymethyl cellulose (prepared in $100 \mathrm{mM}$ sodium acetate buffer, $\mathrm{pH}$ 5.0). The reaction mixture for FPase assay consisted of $0.5 \mathrm{ml}$ of crude enzyme mixed with $0.5 \mathrm{ml}$ of the acetate buffer containing $50 \mathrm{mg}(1 \times 6 \mathrm{~cm})$ of Whatman filter paper no. 1 . The incubation was done at $50{ }^{\circ} \mathrm{C}$ in a thermostat water bath for $10 \mathrm{~min}$ and $30 \mathrm{~min}$ for CMCase and FPase assays respectively. The glucose (reducing sugar) liberated in the reaction was measured by DNS (dinitrosalicylic acid) method (Miller 1959). $\beta$-Glucosidase assay was carried out according to the method by $\mathrm{Ng}$ et al. (2010) with some modifications. The reaction mixture $(1 \mathrm{ml})$ was prepared by mixing $200 \mu \mathrm{l}$ of the appropriately diluted enzyme with $800 \mu \mathrm{l}$ of substrate solution ( $2 \mathrm{mM} \mathrm{pNPG}$ or 4nitrophenyl- $\beta$-D-glucopyranoside), and the incubation was done at $50{ }^{\circ} \mathrm{C}$ for $30 \mathrm{~min}$ in dark. The reaction was terminated by adding $1 \mathrm{ml}$ of $1 \mathrm{M} \mathrm{Na}_{2} \mathrm{CO}_{3}$ solution. The color developed during the assay, as a result of the liberation of pNP, was observed at $405 \mathrm{~nm}$ and quantified using the pNP as a standard.

One unit of enzyme activity is defined as the amount of enzyme required for producing $1 \mu \mathrm{mol}$ of glucose per $\mathrm{ml}$ per minute under assay conditions. The enzyme activity was expressed as units per $\mathrm{ml}(\mathrm{U} / \mathrm{ml})$ for CMCase and $\beta$-glucosidase, and as FPU/ml for filter paper activity.

\section{Determination of cellulose content}

The cellulose content was determined using the method by Ahmed et al. (2010). One gram of the oven-dried biomass (untreated or pretreated) was fluxed with $10 \mathrm{ml}$ of $80 \%$ acetic acid and $1.5 \mathrm{ml}$ of nitric acid for $20 \mathrm{~min}$. Then, contents were filtered using a vacuum pump and solid residues were oven dried at $105{ }^{\circ} \mathrm{C}$ until constant weight. The difference in initial and final weights was used to calculate the cellulose content of biomass.

\section{Statistical analysis}

All the experiments were performed in triplicates. The data points were expressed as mean value \pm SD of three replicates. In addition, analysis of variance was performed statistically using SPSS 16 according to Tukey's test at 5\% probability 
$(p \leq 0.05)$. For each series of values, the significant differences were labeled by lowercase superscript letter.

\section{Results and discussion}

\section{Molecular identification of the cellulolytic strain NAA2}

The comparison of 16S rDNA sequence of strain NAA2 (853 bp) with those of close homologs in the EZTaxon database revealed that isolate was closely related to members of the genus Streptomyces in the family Streptomycetaceae within the class Actinobacteria and order Actinomycetales (classification based on RDP database). The strain NAA2 showed highest 98\% similarity with Streptomyces atrovirens (NRRLB-16357). Also, it exhibited 97-98\% similarity with other Streptomyces strains. Figure 1 depicts the phylogenetic tree showing the evolutionary relationship of Streptomyces sp. NAA2 with closely related strains. Thus, based on nucleotide homology and phylogenetic analysis, the isolate was designated as Streptomyces sp. NAA2.

\section{Optimization of process parameters for carboxymethyl cellulase production}

\section{Effect of pretreatment}

The effect of biomass pretreatment was studied by observing enzyme production using native $P$. hysterophorus biomass, and biomass subjected to steam and alkali-acid pretreatment (Fig. 2). The cellulose content of biomass pretreated using different methods has been given in Table 1. It was found that Streptomyces sp. NAA2 produced the highest amount of CMCases $(0.273 \pm 0.015 \mathrm{U} / \mathrm{ml})$ in the presence of steampretreated biomass. However, a reduction in enzyme production was recorded when alkali-acid-pretreated biomass was

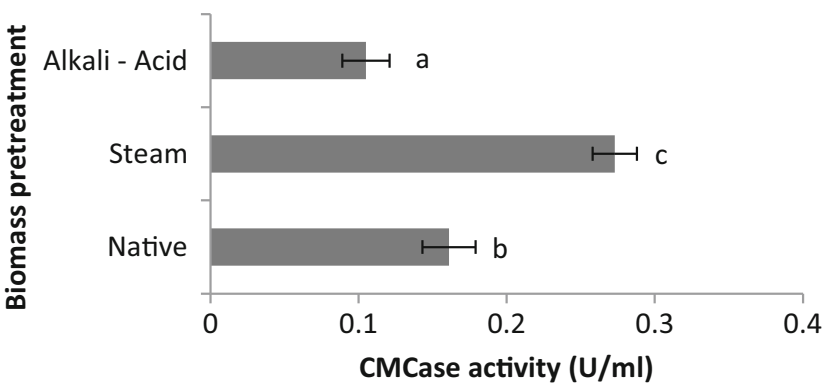

Fig. 2 Effect of biomass pretreatment on CMCase production by Streptomyces sp. NAA2 under SmF conditions

used in production medium despite higher cellulose content in it. The cellulose has inductive effects on the synthesis of cellulases (Todero Ritter et al. 2013), but its accessibility is important during induction. The pretreatment alters the structure of biomass and cellulose accessibility, which may have varying effects on the enzyme yields. Similar to our study, Brijwani and Vadlani (2011) also observed enhanced CMCase production in Trichoderma reesei and Aspergillus oryzae when cultivated on steam-pretreated soybean hulls compared to native, acid-, and alkali-pretreated biomass. The steam pretreatment is known to increase the porosity of the biomass (Brijwani and Vadlani 2011), which could account for increased accessibility of cellulose, consequently increasing production of cellulolytic enzymes. The findings indicate that the structural attributes of biomass are important determining factors for the production of hydrolytic enzymes.

\section{Effect of substrate concentration}

The concentration of cellulosic biomass may have a significant effect on the induction of cellulolytic enzymes. Hence, the effect of substrate (steam pretreated biomass) level was studied by varying its concentration in production medium from $0.5 \%$ to $2.5 \%(w / v)$. The results depicted in Fig. 3 indicate that maximum CMCase production $(0.292 \pm 0.014 \mathrm{U} / \mathrm{ml})$ by Streptomyces sp. NAA2 was observed when the
Fig. 1 Neighbor-joining phylogenetic tree of Streptomyces sp. NAA2 (Bootstrap values have been expressed as percentages of 1000 replications. The sequence of Bacillus sp., NCBI GenBank accession no. EU754025, has been used as an out group)

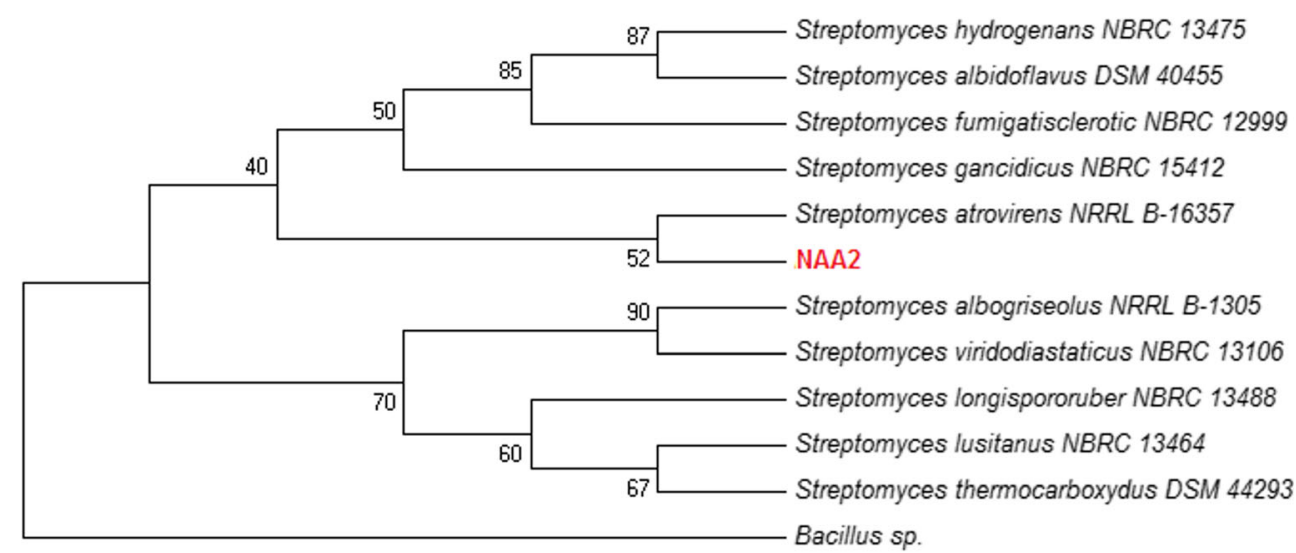


Table 1 Cellulose content of untreated and pretreated P. hysterophorus biomass

\begin{tabular}{ll}
\hline Sample (biomass) & Cellulose content $(\% w / w)$ \\
\hline Untreated & $36.11 \pm 0.39^{\mathrm{a}}$ \\
Steam pretreated & $38.13 \pm 0.17^{\mathrm{b}}$ \\
Alkali-acid pretreated & $56.00 \pm 0.38^{\mathrm{c}}$ \\
\hline
\end{tabular}

Values are mean $\pm \mathrm{SD}$ and the values with different superscripts differ significantly $(p<0.05$; Tukey test $)$

production medium was containing $1 \%$ of biomass. The biomass levels higher or lower than the optimum produced lesser amounts of enzyme. The amount of required substrate varies depending on the type of biomass, microorganisms as well as fermentation conditions. Da Vinha et al. (2011) and El-Naggar and Abdelwahed (2012) have reported that $2 \%(w / v)$ of steam pretreated wheat bran and $1.5 \%(w / v)$ of dilute acid pretreated rice straw were suitable for maximum CMCases production by Streptomyces viridobrunneus SCPE-09 and Streptomyces sp. NEAE-D under SmF conditions, respectively.

\section{Effect of inoculum level}

The amount of inoculum is another important parameter governing enzyme production. In the present study, an increase in inoculum level from 1 disc to 2 discs in the medium caused 1.36-fold increase in CMCase production by Streptomyces sp. NAA2 (Table 2). However, the further rise in inoculum level resulted in a decrease in enzyme activity. This could be attributed to the increased competition between microbial cells (Sabu et al. 2005). Studies have revealed that cellulase production was highest by Cellulomonas sp. (Safdar et al. 2013) and Streptomyces sp. DSK29 (Budihal and Agsar 2015) when $2 \%(v / v)$ and $1 \times 10^{8}$ spores $/ \mathrm{ml}$ inoculum were used in medium containing potato waste and sorghum stover respectively.
Table 2 Effect of inoculum level, Incubation time and shaking speed on CMCase production by Streptomyces sp. NAA2 under $\mathrm{SmF}$ conditions

\begin{tabular}{lc}
\hline Parameter & CMCase activity $(\mathrm{U} / \mathrm{ml})$ \\
\hline Inoculum level & $($ no. of discs) \\
1 & $0.287 \pm 0.008^{\mathrm{a}}$ \\
2 & $0.392 \pm 0.015^{\mathrm{d}}$ \\
3 & $0.325 \pm 0.015^{\mathrm{b}}$ \\
4 & $0.331 \pm 0.011^{\mathrm{b}}$ \\
5 & $0.326 \pm 0.006^{\mathrm{b}}$ \\
Incubation time $($ days $)$ \\
2 & $0.134 \pm 0.011^{\mathrm{a}}$ \\
3 & $0.291 \pm 0.011^{\mathrm{b}}$ \\
4 & $0.453 \pm 0.011^{\mathrm{d}}$ \\
5 & $0.451 \pm 0.009^{\mathrm{d}}$ \\
6 & $0.389 \pm 0.005^{\mathrm{c}}$ \\
7 & $0.393 \pm 0.005^{\mathrm{c}}$ \\
8 & $0.387 \pm 0.005^{\mathrm{c}}$ \\
Shaking speed $(\mathrm{rpm})$ \\
100 & $0.439 \pm 0.014^{\mathrm{a}}$ \\
120 & $0.943 \pm 0.006^{\mathrm{c}}$ \\
150 & $0.967 \pm 0.016^{\mathrm{c}}$ \\
180 & $0.636 \pm 0.017^{\mathrm{b}}$ \\
\hline
\end{tabular}

Values are means \pm standard deviation and the values with the different superscripts differ significantly $(p<0.05$; Tukey test $)$

\section{Effect of initial pH}

The production of enzymes is strongly influenced by $\mathrm{pH}$ of fermentation medium. Therefore, the effect of initial $\mathrm{pH}$ was determined on carboxymethyl cellulase production by Streptomyces sp. NAA2. The actinomycete exhibited maximum CMCase activity, i.e., $0.388 \pm 0.008 \mathrm{U} / \mathrm{ml}$ when the initial $\mathrm{pH}$ of the fermentation medium was 6.5 (Fig. 4a). Very high or low $\mathrm{pH}$ values, however, caused a significant reduction in enzyme activity. The $\mathrm{pH}$ requirements for obtaining the

Fig. 3 Effect of substrate concentration on CMCase production by Streptomyces sp. NAA2 under SmF conditions

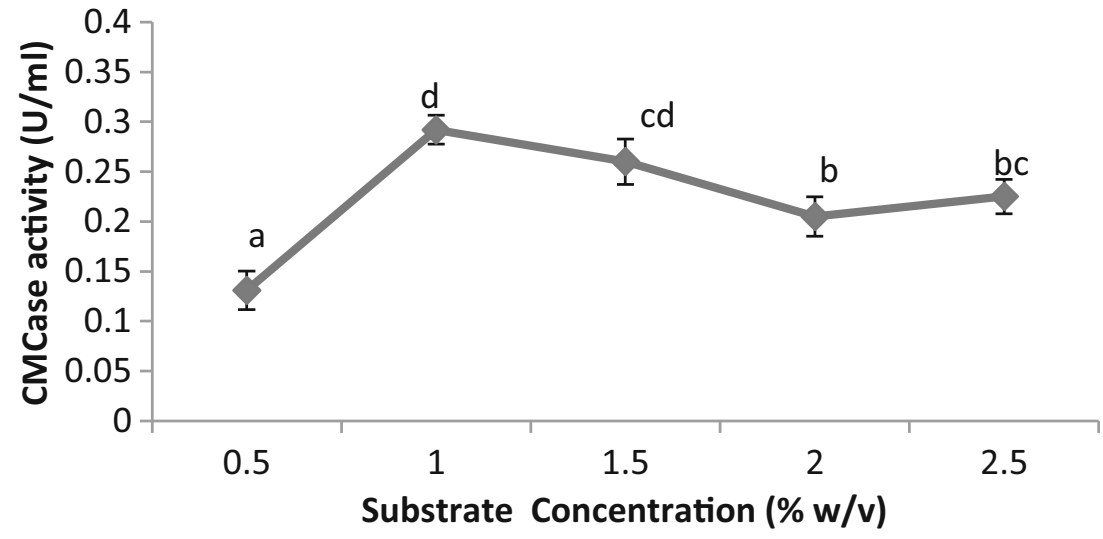



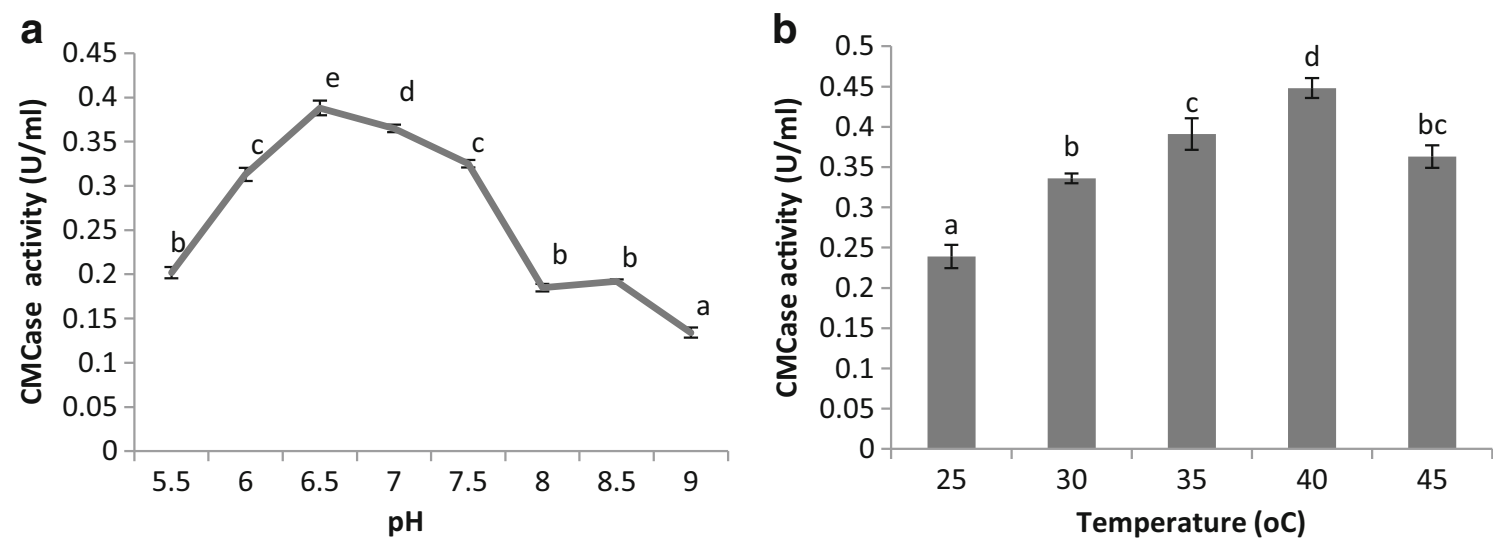

Fig. 4 Effect of $\mathbf{a}$ initial $\mathrm{pH}$ and $\mathbf{b}$ temperature on CMCase production by Streptomyces sp. NAA2 under SmF conditions

highest levels of extracellular cellulases vary with the microorganisms and substrates used for their cultivation. Highest enzyme production was detected at $\mathrm{pH} 7.0$ in Streptomyces actuosus (Murugan et al. 2007) and Streptomyces sp. J2 (Jaradat et al. 2008) in a medium containing CMC, and at pH 6.0 in Streptomyces ruber in a rice straw-supplemented medium (El-sersy et al. 2010). The pH exerts its effect by inducing changes in cell morphology and also has a role in the transport of the enzymes (Mrudula and Murugammal 2011).

\section{Effect of temperature}

The excretion of extracellular cellulases is affected by the permeability of the cell membrane, and temperature has a profound effect on permeability (Behera et al. 2016). Therefore, the effect of incubation temperature was evaluated over a range of $25^{\circ} \mathrm{C}$ to $45^{\circ} \mathrm{C}$ (Fig. 4b). The results demonstrated a gradual increase in CMCase production with the increase in temperature from $25{ }^{\circ} \mathrm{C}(0.239 \pm 0.015 \mathrm{U} / \mathrm{ml})$ to $40{ }^{\circ} \mathrm{C}(0.448 \pm 0.015 \mathrm{U} / \mathrm{ml})$. Thereafter, a decline in enzyme production was detected beyond optimum temperature.
Similar to our observations, $40{ }^{\circ} \mathrm{C}$ temperature was found ideal for highest carboxymethyl cellulase production by Streptomyces ruber (El-sersy et al. 2010) and S. albidoflavus strain SAMRC-UFH5 in media containing rice straw and CMC, respectively (Fatokun et al. 2016). A decline in enzyme activity recorded beyond optimum temperature could result from denaturation of enzymes at higher temperatures (Karim et al. 2015; Behera et al. 2016).

\section{Effect of incubation time}

The optimum incubation time for enzyme production varies with the type of microorganisms as well as the substrate. To analyze the effect of time course on CMCase production by Streptomyces sp. NAA2, flasks were incubated for different time periods, i.e., 2 to 8 days. A nearly constant increase in enzyme production was recorded up to the 4th day $(0.453 \pm$ $0.011 \mathrm{U} / \mathrm{ml})$, and the production remained unchanged on day $5(0.451 \pm 0.009 \mathrm{U} / \mathrm{ml})$, whereas a decline was observed on increasing incubation time to 6 days $(0.389 \pm 0.005 \mathrm{U} / \mathrm{ml})$ (Table 2). Further incubation, however, did not result in significant variation in enzyme production from 6 to 8 days. A

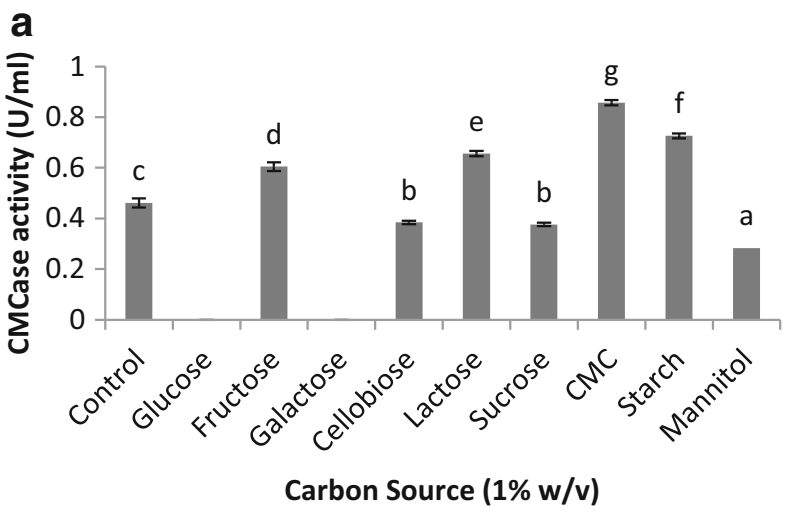

b

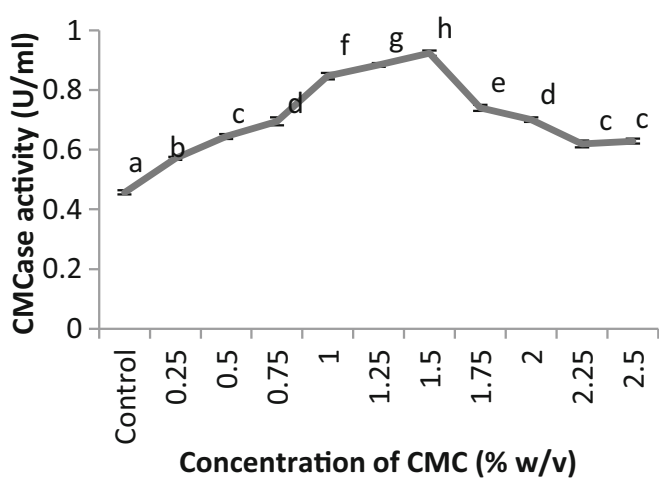

Fig. 5 Effect of a different sources of carbon and $\mathbf{b}$ CMC concentrations on CMCase production by Streptomyces sp. NAA2 under SmF conditions 
Table 3 Effect of substrate concentration on the TRS yield from hydrolysis of pretreated P. hysterophorus biomass using cellulase activity of Streptomyces sp. NAA2

\begin{tabular}{|c|c|c|c|c|c|}
\hline \multirow[t]{2}{*}{ Time (h) } & \multicolumn{5}{|c|}{ Total reducing sugars ( $\mathrm{g} / \mathrm{g}$ biomass) at different substrate concentrations $(\% \mathrm{w} / \mathrm{v})$} \\
\hline & 1.0 & 2.0 & 3.0 & 5.0 & 7.0 \\
\hline 24 & $0.031 \pm 0.0013^{\mathrm{a}}$ & $0.045 \pm 0.0012^{\mathrm{c}}$ & $0.042 \pm 0.0014^{\mathrm{c}}$ & $0.038 \pm 0.0014^{\mathrm{b}}$ & $0.035 \pm 0.0011^{\mathrm{b}}$ \\
\hline 48 & $0.048 \pm 0.0011^{\mathrm{a}}$ & $0.062 \pm 0.0013^{\mathrm{c}}$ & $0.059 \pm 0.0011^{\mathrm{c}}$ & $0.052 \pm 0.0011^{\mathrm{b}}$ & $0.048 \pm 0.0016^{\mathrm{a}}$ \\
\hline 72 & $0.073 \pm 0.0014^{\mathrm{a}}$ & $0.094 \pm 0.0011^{\mathrm{e}}$ & $0.086 \pm 0.0010^{\mathrm{d}}$ & $0.081 \pm 0.0010^{\mathrm{c}}$ & $0.077 \pm 0.0013^{\mathrm{b}}$ \\
\hline 96 & $0.099 \pm 0.0014^{\mathrm{b}}$ & $0.113 \pm 0.0009^{\mathrm{d}}$ & $0.103 \pm 0.0010^{\mathrm{c}}$ & $0.098 \pm 0.0013^{\mathrm{b}}$ & $0.094 \pm 0.0013^{\mathrm{a}}$ \\
\hline
\end{tabular}

Values are means \pm standard deviation. The values with similar superscripts in each row do not differ significantly $(p<0.05$; Tukey test) decrease in enzyme yields beyond optimum time is associated with increased biomass production and depletion of nutrients in the medium. The carboxymethyl cellulase titers were highest in Streptomyces sp. BRC1 and Streptomyces sp. BRC2 at 72-88 h (Chellapandi and Jani 2008), and on day 6 in Streptomyces viridobrunneus SCPE09 when cellulose and wheat bran were used as the substrates respectively (Da Vinha et al. 2011).

\section{Effect of carbon supplement and its concentration}

The supplementation of additional carbon source (other than the cellulosic substrate) may have an inductive effect on cellulases synthesis. Therefore, production medium containing steam-pretreated substrate was supplemented with different carbon sources. It was found that CMC caused the highest enzyme production in Streptomyces sp. NAA2, i.e., $0.857 \pm$ $0.010 \mathrm{U} / \mathrm{ml}$ compared to $0.461 \pm 0.010 \mathrm{U} / \mathrm{ml}$ in control (without any carbon supplement) (Fig. 5a). The fructose, lactose, and starch also showed a positive effect on CMCase production by Streptomyces sp. NAA2 $(0.605 \pm 0.017 \mathrm{U} / \mathrm{ml}, 0.656 \pm$ $0.011 \mathrm{U} / \mathrm{ml}$, and $0.726 \pm 0.010 \mathrm{U} / \mathrm{ml}$ CMCase activity, respectively). On the other hand, glucose and galactose were strongly repressive, while cellobiose, sucrose, and mannitol also showed inhibitory effect. Several studies have also documented an inhibitory effect of glucose and several other simple sugars on induction of cellulases in T. reesei (Dashtban et al. 2011). Amore et al. (2013) have reported repression of several cellulases in the presence of mannitol. Furthermore, while evaluating the effect of CMC levels, $1.5 \%(w / v)$ concentration was found most suitable for obtaining highest CMCase titers $(0.924 \pm 0.009 \mathrm{U} / \mathrm{ml})$, followed with a drop on a further rise in its concentration (Fig. 5b).

\section{Effect of shaking speed}

The agitation speed has a significant effect on enzyme production by bacteria (Haritha et al. 2012). It influences the growth of cellulase-producing microbes by governing levels of dissolved oxygen in the fermentation medium (Deka et al. 2013) and also ensures uniform mixing of medium contents (Srilakshmi et al. 2017). In Streptomyces sp. NAA2, the study on the effect of agitation speed indicated that the highest CMCase production $(0.967 \pm 0.016 \mathrm{U} / \mathrm{ml})$ was recorded at 120 or $150 \mathrm{rpm}$ (Table 2). Very high speeds, on the other hand, cause lysis of microbial cells (Haritha et al. 2012) consequently reducing the
Fig. 6 Effect of substrate concentration on saccharification of pretreated P. hysterophorus biomass with cellulase enzyme from Streptomyces sp. NAA2

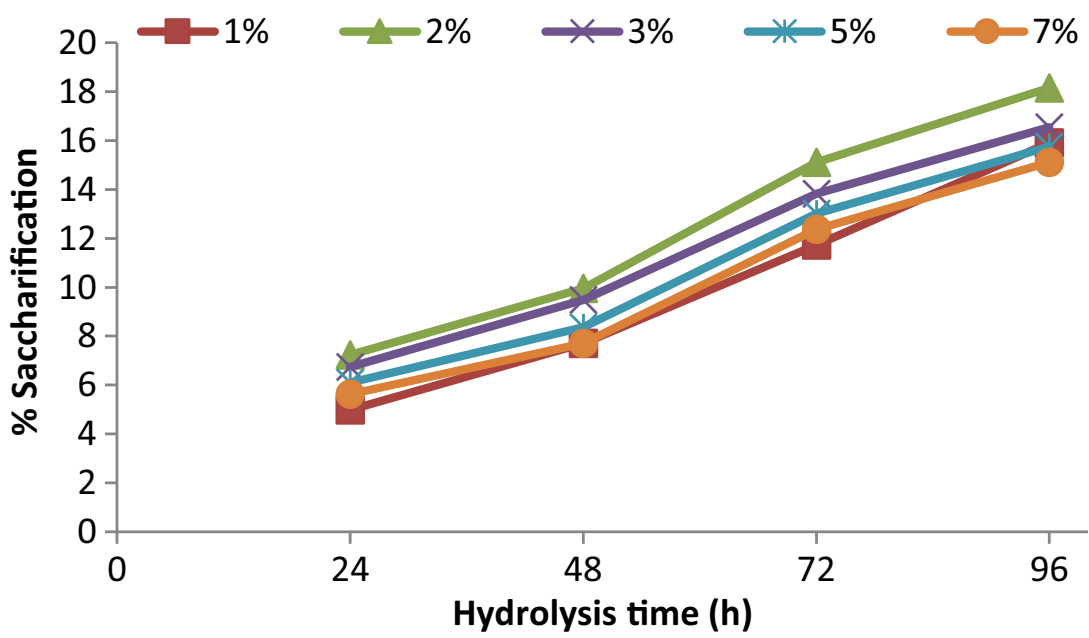


Table 4 Effect of enzyme concentration on the TRS yield from hydrolysis of pretreated $P$. hysterophorus biomass using cellulase activity of Streptomyces sp. NAA2

\begin{tabular}{|c|c|c|c|c|}
\hline \multirow[t]{2}{*}{ Time (h) } & \multicolumn{4}{|c|}{ Total reducing sugars (g/g biomass) at different enzyme loadings (FPU/100 ml) } \\
\hline & 10.0 & 20.0 & 30.0 & 40.0 \\
\hline 24 & $0.031 \pm 0.0013^{\mathrm{a}}$ & $0.035 \pm 0.0017^{\mathrm{b}}$ & $0.045 \pm 0.0012^{\mathrm{d}}$ & $0.041 \pm 0.0011^{\mathrm{c}}$ \\
\hline 48 & $0.048 \pm 0.0011^{\mathrm{a}}$ & $0.051 \pm 0.0016^{\mathrm{a}}$ & $0.064 \pm 0.0013^{\mathrm{c}}$ & $0.058 \pm 0.0017^{\mathrm{b}}$ \\
\hline 72 & $0.073 \pm 0.0014^{\mathrm{a}}$ & $0.081 \pm 0.0014^{\mathrm{b}}$ & $0.094 \pm 0.0011^{\mathrm{d}}$ & $0.090 \pm 0.0016^{\mathrm{c}}$ \\
\hline 96 & $0.089 \pm 0.0014^{\mathrm{a}}$ & $0.100 \pm 0.0016^{\mathrm{b}}$ & $0.113 \pm 0.0009^{\mathrm{d}}$ & $0.109 \pm 0.0011^{\mathrm{c}}$ \\
\hline
\end{tabular}

Values are means \pm standard deviation and the values with similar superscripts in each row do not differ significantly $(p<0.05$; Tukey test) enzyme titers. Fatokun et al. (2016) observed the highest cellulase production by Streptomyces sp. at $100 \mathrm{rpm}$.

Under optimized conditions (i.e., in 4-5 days, using $1 \% \mathrm{w} / \mathrm{v}$ steam-pretreated $P$. hysterophorus biomass as substrate, 2 discs of inoculum, initial $\mathrm{pH} 6.5$, temperature $40{ }^{\circ} \mathrm{C}, 120-150 \mathrm{rpm}$, and $1.5 \% \mathrm{CMC}$ as additional carbon supplement), Streptomyces sp. NAA2 exhibited $0.967 \pm 0.016 \mathrm{U} / \mathrm{ml}$ CMCase activity, 0.116 $\pm 0.08 \mathrm{FPU} / \mathrm{ml}$ total cellulase (FPase) activity, and $0.22 \pm$ $0.012 \mathrm{U} / \mathrm{ml} \beta$-glucosidase activity.

\section{Biomass saccharification}

The saccharification study was carried out to maximize production of sugars from pretreated biomass by optimizing the levels of the substrate as well as the enzyme produced from Streptomyces sp. NAA2. While studying the effect of biomass concentration, it was observed that saccharification yield increased initially with the rise in substrate levels. Further increase in substrate concentration, however, led to a decrease in hydrolysis yield. Highest levels of saccharification yield, i.e., $18.2 \%$ of biomass (TRS $=0.113 \mathrm{~g} / \mathrm{g}$ biomass, Table 3 ) was obtained in $96 \mathrm{~h}$ when substrate level was $2 \%(w / v)$ (Fig. 6). The initial rise in TRS levels could be attributed to the requirement of an optimum amount of substrate proportional to enzyme levels present in the reaction mixture. The decrease in the hydrolysis yield at high substrate loading might occur due to adsorption of enzymes on to unproductive sites in the biomass, mass transfer limitations, or end-product inhibition of enzyme due to higher sugar levels (Gama et al. 2017).

The study of the effect of enzyme loadings on saccharification of biomass with actinomycete cellulase enzyme indicated that the rise in enzyme loading from $10 \mathrm{FPU}$ to $30 \mathrm{FPU}$ in reaction volume resulted in an increase in hydrolysis yield. The maximum level of TRS $(0.113 \mathrm{~g} / \mathrm{g}$ biomass, or $0.202 \mathrm{~g} / \mathrm{g}$ cellulose, Table 4) and saccharification yield $(18.2 \%)$ was achieved in $96 \mathrm{~h}$ when enzyme level was 30 FPU (Fig. 7). However, a further rise in the enzyme concentration resulted in a decrease in saccharification yield.

Hsu et al. (2011) have reported production of $53.1 \mathrm{~g} / 100 \mathrm{~g}$ TRS from acid-pretreated corncob using Sterptomyces sp. T3-1, when sacchrification was carried out by cultivating it directly in the medium containing biomass. Kshirsagar et al. (2015) have shown enhanced production of cellulase from Nocardiopsis sp. $\mathrm{KNU}$ and achieved the release of $>30 \mathrm{mg} / \mathrm{g}$ sugars when crude enzyme from this strain was used for hydrolysis of $\mathrm{NaOH}-$ pretreated rice husk, at $15 \%$ biomass loading in the hydrolysis time of $96 \mathrm{~h}$. Ventorino et al. (2016) have also isolated several actinomycetes strains from degrading biomass and used cellulases from the strains exhibiting high cellulolytic potential for saccharification of pretreated biomass of Arundo donax. The
Fig. 7 Effect of enzyme concentration on saccharification of pretreated $P$. hysterophorus biomass with cellulase enzyme from Streptomyces sp. NAA2

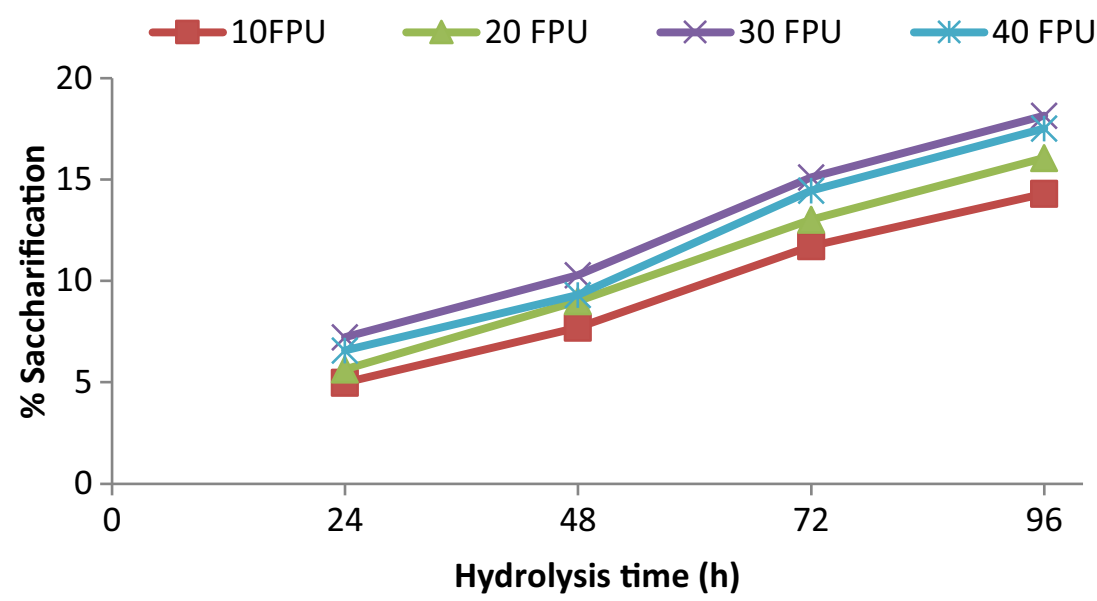


results indicated that endo-cellulase from Streptomyces argenteolus AE58P yielded $76 \%$ of glucose when biomass was pretreated with Accellerase 1500. Adiguzel and Tuncer (2017) produced endoglucanase and endoxylanase from Actinomadura geliboluensis, partially purified the enzymes and applied their mixture for saccharification of alkali-pretreated wheat straw. They achieved production of $265.12 \mathrm{mg} / \mathrm{g}$ sugars using the cocktail of hemicellulolytic and cellulolytic enzyme from the actinomycete.

\section{Conclusion}

The search for cellulase-producing isolates has been an interest of researchers for many years. Despite exploring a wide range of microbial species, studies are still continued and new microbes are being tapped for their cellulolytic potential. The present study reveals the cellulase production potential of Streptomyces sp. NAA2 and the optimization study resulted in 6-fold increase in CMCase production by it. The saccharification study showed that cellulases produced from strain NAA2 could effectively hydrolyze alkali-acid pretreated $P$. hysterophorus biomass resulting in the production of the considerable amount of TRS. In future, the study can be extended for bioethanol production from $P$. hysterophorus. The study also indicates that $P$. hysterophorus can be used as an effective substrate for bioethanol production or biosynthesis of cellulases. Its availability and abundance can be leveraged as an economical substrate for applications at industrial scales. Also, the hydrolytic potential of actinomycete NAA2 can be used in many other industrial applications including cellulosic bioconversions of diverse biomass.

Funding The present study was supported by University Grants Commission (UGC) Government of India, through the scheme of University Grants Commission-Junior Research Fellowship (UGCJRF) in the discipline of Science, Humanities, and Social Sciences.

\section{Compliance with ethical standards}

Conflict of interest The authors declare that they have no conflict of interest.

Research involving human participants and/or animals This article does not contain any studies with human or animal subjects.

Informed consent Not applicable.

Publisher's note Springer Nature remains neutral with regard to jurisdictional claims in published maps and institutional affiliations.

\section{References}

Adiguzel AO, Tuncer M (2017) Production and characterization of partially purified thermostable endoxylanase and endoglucanase from novel Actinomudura geliboluensis and the biotechnological applications in the sachharification of lignocellulosic biomass. BioResources 12:2528-2547

Ahmed I, Zia MA, Iqbal HMN (2010) Bioprocessing of proximally analyzed wheat straw for enhanced cellulase production through process optimization with Trichoderma viride under SSF. World Acad Sci Eng Technol 37:1208-1214

Amore A, Giacobbe S, Faraco V (2013) Regulation of cellulase and hemicellulase gene expression in fungi. Curr Genomics 14:230-249

Behera BC, Mishra RR, Singh SK, Dutta SK, Thatoi H (2016) Cellulase from Bacillus licheniformis and Brucella sp. isolated from mangrove soils of Mahanadi river delta, Odisha, India. Biocatal Biotransformation 34:44-53

Bettache A, Messis A, Boufassa L, Boucherba N, Belhamiche N, Kecha M, Copinet E, Duchiron F, Benallaoua S (2014) Production of endoglucanase by a novel strain Streptomyces sp. TKJ2 and its optimization under submerged fermentation. Biotechnol (Rajkot) 10: 29-36

Brijwani K, Vadlani PV (2011) Cellulolytic enzymes production via solid-state fermentation: effect of pretreatment methods on physicochemical characteristics of substrate. Enzym Res 2011

Budihal SR, Agsar D (2015) Exploration of agrowastes for the production of cellulase by Streptomyces DSK29 under submerged and solid state systems. Int J Curr Microbiol App Sci 4:681-689

Chellapandi P, Jani HM (2008) Production of endoglucanase by the native strains of Streptomyces isolates in submerged fermentation. Braz J Microbiol 39:122-127

Choudhary J, Saritha M, Nain L, Arora A (2014) Enhanced Saccharification of steam-pretreated rice straw by commercial cellulases supplemented with xylanase. J Bioproces Biotech 4:1-6

Da Vinha FNM, Gravina-Oliveira MP, Franco MN, Macrae A, da Silva Bon EP, Nascimento RP, Coelho RRR (2011) Cellulase production by Streptomyces viridobrunneus SCPE-09 using lignocellulosic biomass as inducer substrate. Appl Biochem Biotechnol 164:256-267

Dashtban M, Buchkowski R, Qin W (2011) Effect of different crabon sources on cellulase production by Hypocrea jecorina (Trichoderma reesei) strains. Int J Biochem Mol Biol 2:274-286

Deka D, Das SP, Sahoo N, Das D, Jawed M, Goyal D, Goyal A (2013) Enhanced cellulase production from Bacillus subtilis by optimizing physical parameters for bioethanol production. ISRN Biotechnol: 2013

El-Naggar NEA, Abdelwahed NAM (2012) Optimization of process parameters for the production of alkali-tolerant carboxymethyl cellulase by newly isolated Streptomyces sp. strain NEAE-D. Afr J Biotechnol 11:1185-1196

El-sersy NA, Abd-elnaby H, Abou-elela GM, Ibrahim HA, El-toukhy NM (2010) Optimization, economization and characterization of cellulase produced by marine Streptomyces ruber. Afr J Biotechnol 9:6355-6364

Escobar JC, Lora ES, Venturini OJ, Yáñez EE, Castillo EF, Almazan O (2009) Biofuels: environment, technology and food security. Renew Sust Energ Rev 13:1275-1287

Fatokun EN, Nwodo UU, Okoh AI (2016) Classical optimization of cellulase and xylanase production by a marine Streptomyces species. Appl Sci 6:286

Gama R, Van Dyk JS, Burton MH, Pletschke BI (2017) Using an artificial neural network to predict the optimal conditions for enzymatic hydrolysis of apple pomace. 3 Biotech 7:1-10

Ghose TK (1987) Measurement of cellulase activities. Pure Appl Chem 59:257-268

Gnanavel I (2013) Parthenium hyterophorus L.: a major threat to natural and agro eco-systems in India. Sci Int 1:124-131

Haritha R, Sivakumar K, Swathi A, Jagan Mohan YSYV, Ramana T (2012) Chracaterization of marine Streptomyces carpaticus and 
optimization of conditions for production of extracellular protease. Microbiol J 2:23-35

Hsu CL, Chang KS, Lai MZ, Chang TC, Chang YH, Jang HD (2011) Pretreatment and hydrolysis of cellulosic agricultural wastes with a cellulase-producing Sterptomyces for bioethnaol production. Biomass Bioenergy 35:1878-1884

Imran M, Anwar Z, Irshad M, Asad MJ, Ashfaq H (2016) Cellulase production from species of fungi and bacteria from agricultural wastes and its utilization in industry: a review. Adv Enzyme Res 4:44-55

Jaradat Z, Dawagreh A, Ababneh Q, Saadoun I (2008) Influence of culture conditions on cellulase production by Streptomyces Sp. (strain J2). Jordan J Biol Sci 1:141-146

Karim A, Nawaz MA, Aman A, Qader SAU (2015) Hyper production of cellulose degrading endo $(1,4) \beta$-D-glucanase from Bacillus licheniformis KIBGE-IB2. J Radiat Res Appl Sci 8:160-165

Kim OS, Cho YJ, Lee K, Yoon SH, Kim M, Na H et al (2012) Introducing EzTaxon-e: a prokaryotic 16s rRNA gene sequence database with phylotypes that represent uncultured species. Int J Syst Evol Microbiol 62:716-721

Kshirsagar SD, Waghmare PR, Loni PC, Patil SA, Govindwar SP (2015) Dilute acid pretreatment of rice straw, structural characterization and optimization of enzymatic hydrolysis conditions by response surface methodology. RSC Adv 5:46525-46533

Kumar S, Stecher G, Tamura K (2016) MEGA7: molecular evolutionary genetics analysis version 7.0 for bigger datasets. Mol Biol Evol 33: 1870-1874

Mandels M, Reese ET (1957) Induction of cellulase in Trichoderma viride as influenced by carbon sources and metals. J Bacteriol 73: 269-278

Miller GL (1959) Use of dinitrosalicylic acid reagent for determination of reducing sugar. Anal Chem 31:426-428

Mrudula S, Murugammal R (2011) Production of cellulase by Aspergillus niger under submerged and solid state fermentation using coir waste as a substrate. Braz J Microbiol 42:1119-1127

Murugan M, Srinivasan M, Sivakumar K, Sahu MK, Kannan L (2007) Characterization of an actinomycete isolated from the estuarine finfish, Mugil cephalus Lin. (1758) and its optimization for cellulase production. J Sci Ind Res 66:388-393

$\mathrm{Ng}$ IS, Li CW, Chan SP et al (2010) High-level production of a thermoacidophilic $\beta$-glucosidase from Penicillium citrinum YS405 by solid-state fermentation with rice bran. Bioresour Technol 101: 1310-1317

Padilha IQM, Carvalho LCT, Dias PVS, Grisi TCSL, Silva FL, Santos FSM, Araújo DAM (2015) Production and characterization of thermophilic carboxymethyl cellulase synthesized by Bacillus sp. growing on sugarcane bagasse in submerged fermentation. Braz $\mathrm{J}$ Chem Eng 32:35-42

Sabu A, Pandey A, Daud MJ, Szakacs G (2005) Tamarind seed powder and palm kernel cake: two novel agro residues for the production of tannase under solid state fermentation by Aspergillus niger ATCC 16620. Bioresour Technol 96:1223-1228

Sadhu S, Maiti TK (2013) Cellulase production by bacteria: a review. $\mathrm{Br}$ Microbiol Res J 3:235-258

Safdar A, Irfan M, Nadeem M, Syed Q (2013) Carboxymethyl cellulase production from newly isolated Cellulomonas $\mathrm{sp}$. in submerged fermentation. Hacettepe J Biol Chem 41:179-185

Saini A, Aggarwal NK, Sharma A, Kaur M, Yadav A (2014) Utility potential of Parthenium hysterophorus for its strategic management. Adv Agric 2014:1-16

Saini A, Aggarwal NK, Yadav A (2016) Cellulolytic potential of actinomycetes isolated from different habitats. Bioengineering and Bioscience 4:88-94

Sarkar N, Ghosh SK, Bannerjee S, Aikat K (2012) Bioethanol production from agricultural wastes : an overview. Renew Energy 37:19-27

Srilakshmi A, Sai Gopal DVR, Narasimha G (2017) Impact of bioprocess parameters on cellulase production by Purpureocillium lilacinum isolated from forest soil. Int J Pharm Bio Sci 8:157-165

Sukumaran RK, Singhania RR, Mathew GM, Pandey A (2009) Cellulase production using biomass feed stock and its application in lignocellulose saccharification for bio-ethanol production. Renew Energy 34:421-424

Thompson JD, Gibson TJ, Plewniak F, Jeanmougin F, Higgins DG (1997) The CLUSTAL X windows interface: flexible strategies for multiple sequence alignment aided by quality analysis tools. Nucleic Acids Res 25:4876-4882

Todero Ritter CE, Camassola M, Zampieri D, Silveira MM, Dillon AJP (2013) Cellulase and xylanase production by Penicillium echinulatum in submerged media containing cellulose amended with sorbitol. Enzyme Res 2013. https://doi.org/10.1155/2013/ 240219

Ventorino V, Ionata E, Birolo L, Montella S, Marcolongo L, de Chiaro A, Espresso F, Faraco F, Pepe O (2016) Lignocellulose-adapted endocellulase producing Streptomyces strains for bioconversion of cellulose-based materials. Front Microbiol 7:2061

Xia X, Xie Z (2001) DAMBE: software package for data analysis in molecular biology and evolution. J Hered 92:371-373 